\title{
Remembering the 1998 Indonesian Sorcerers Massacre: Memory of Tragedy and Trauma in Intan Andaru's Perempuan Bersampur Merah (Woman in Red Scarf)
}

\author{
Eggy Fajar Andalas', Hidayah Budi Qur'ani ${ }^{2}$ \\ ${ }^{1}$ Assistant Professor, Department of Indonesian Language Education, Universitas \\ Muhammadiyah Malang,eggy@umm.ac.id, ORCID: oooo-0oo2-0107-7849 \\ ${ }^{2}$ Assistant Professor, Department of Indonesian Language Education, Universitas \\ Muhammadiyah Malang, qurani@umm.ac.id, ORCID: oooo-0oo2-5441-9136
}

\begin{abstract}
After the collapse of the New Order government, in the 1998-1999, hundreds of people who were considered to be sorcerers were killed, especially in Banyuwangi. In the obscurity, Intan Andaru has narrated these events into her work. Her novel, Perempuan Bersampur Merah (Woman in Red Scarf), tells massacre story form the voiceless accused sorcerer's point of view. This article aims to discuss the representational character of the 1998 Indonesian sorcerer massacre as depicted in the work of fiction. This research uses a psycho-historical approach. The data collection technique was done by using a note-taking technique. The analysis technique is carried out by the stages of presenting data, reducing data, and drawing conclusions. The results showed that there was no authentic evidence to support the accusation that the person who was killed was actually a sorcerer. As a result, cultural trauma is an important part of the psychological suffering experienced by the victim's family. This trauma cannot be erased because the stigmata as a descendant of a sorcerer will always be attached to the victim's family. This novel revives the social and cultural memorial structure of the 1998 Indonesian massacre in the form of individual aesthetic mediation to activate historical memory.
\end{abstract}

Keywords: banyuwangi 1998, sorcerer, memory, tragedy, trauma

\section{Introduction}

After the fall of the New Order government, in the 1998-1999 period, hundreds of people who were considered to be sorcerers ${ }^{i}$ were massacred in Indonesia. This massacre took place in the Banyuwangi area with more than a hundred cases of murder and dozens of people being tortured or dumped, while in South Malang ten victims died as a result of being considered sorcerers (Herriman, 2006a: 130; Siegel, 2001: 1, 2006: 111). This incident is one of the dark histories of human slaughter in Indonesia, apart from the G/30/ S/PKI in 1965 (Vickers, 2010). Until now, there is no clarity regarding the party responsible for the incident. On the one hand, the opposition to the New Order government has described the state as the actor most responsible for this incident and the community as the victim (Cribb, 2001, 2002; Parker, 2003). Moreover, there is a perception that the New Order is just a scapegoat (Colombijn \& Lindblad, 2002; Herriman, 2007b, 2009, 2012).

(c) AesthetixMS 2021. This Open Access article is published under a Creative Commons Attribution Non-Commercial 4.0 International License (http://creativecommons.org/licenses/by-nc/4.o/), which permits non-commercial re-use, distribution, and reproduction in any medium, provided the original work is properly cited. For citation use the DOI. For commercial re-use, please contact editor@rupkatha.com. 
In response to this incident, researchers from various scientific fields expressed their views. Researchers approach the events of the 1998 sorcerers massacre differently. First, the research looks at the role of the state in the 1998 Banyuwangi sorcerers massacre (Herriman, 2007b; Retsikas, 2006). These researchers looked at the sociocultural basis of dissociation and the reasons behind the terror perpetrated by the state apparatus. Second, Herriman (2015a); Juang, Erviantono, \& Azhar (1998); and Winandi (2001), state that protection for victims of human rights violations, namely "dukun santet", or sorcerer is not yet available in the law. As a result, the government as the controller of power uses various social controls over other groups to dominate. Third, research looks at the perspectives of local communities in responding to the cases of sorcerer massacre (Herriman, 2006, 2007a, 2009; Siegel, 2001). Fourth, research focuses on rumors that develop in the mass media and word of mouth (Herriman, 2010, 2015a; Wessing, 1996). Fifth, research looks at existing problems based on the anthropological conditions of the Banyuwangi community (Herriman, 2012; Mahony, 2002; Siegel, 2002). Sixth, research focuses on the relationship between sorcerer cases and magical rituals concerning capitalism (Herriman, 2015b). Seventh, research scrutinizes gender issues in the magical ritual practice of sorcerer in Banyuwangi (Retsikas, 2010).

Various approaches have been used to find palpable reason on the massacre of people who are considered to be sorcerers in Banyuwangi. Various views differ from each other in seeing the role of the state in the case. Apart from this, as a result of this incident, various rumors have also emerged in the community, by word of mouth, and in the mass media. However, until now, after more than 20 years of events, there has been no statement regarding the actual event. As if this incident just disappeared in the historical memory of the Indonesian nation.

In Indonesian literary discourse, in fact, several works use the setting of the 1998 Banyuwangi "sorcerer" event in their works, including Kerudung Santet Gandrung (Gandrung Santet Veil) (Singodimayan, 2003), Kiamat Para Dukun (Doomsday of Sorcerer) (Hariadi, 2004), and Perempuan Besampur Merah (Woman in Red Scarf) (Andaru, 2019). Unlike the first two works, Perempuan Bersampur Merah (Woman in Red Scarf) recounts the events of this tragedy in the firstperson perspective as a child victim of the tragedy. The author focuses on the psychologicalhistorical dimension of the 1998 Banyuwangi tragedy, which is unspoken in the mainstream discourse. Novel Perempuan Bersampur Merah (Woman in Red Scarf) tells the story of Sari's investigation, the main character, for the truth of the murder of her father who is accused of being a sorcerer. He not only lost his father, but also his uncle and close family. As a result of his father's murder, because he was suspected of being a sorcerer, his famiy's life fell apart. Based on the innocence of his father who was the victim of the murder of his village residents, she began to collect pieces of evidence and investigate the truth. He wanted to reveal the mastermind behind his father's murder. Through the quest to uncover the dark stories in his life, the author develops a narrative line on several events that led him to find answers to the dark tragedy that his family experienced 14 years ago.

In this work, Intan Andaru highlights the dimensions of the Banyuwangi sorcerer massacre from the perspective of the victim. Not only that, the author creates an aesthetic dialectic space to commemorate the story of the massacre experienced by victims who are considered to be sorcerer. Through her work, the author offers a different perspective in understanding the incident from the point of view of the victim who has not been voiced. As far as the writer's search, the object of this research data has never been studied before. Even so, in addition to the foreign researchers previously mentioned, several Indonesian researchers have also researched the existence of sorcerer in Banyuwangi. First, Herniti (2012), through his study of Javanese people's belief in sorcerer, occult message, and spirits, shows that people believe in the existence of these three in this world. This 
cannot be separated from the beliefs of animism, dynamism, and totemism which are still deeply rooted in people's lives. Second, Khusairi, (2015) examined violence and the issue of sorcerer in Banyuwangi. According to him, this happened due to cultural, religious, and politicization factors to expand violence. Even so, sorcerer does not always have a negative meaning. Third, Asrumi (2017), through his study shows that the main function of sorcerer in the social and cultural life of the Banyuwangi community has positive and negative persona. In its function as a positive thing, sorcerer is used to change the feelings of the intended person to be happy or prefer the person who does sorcery, while the negative function is to embarrass or harm the person who is being targeted. Fourth, Subekti \& Kusairi (2018), shows that the existence of santet and sorcerers in Banyuwangi to date cannot be seen from a partial perspective. The existence of Islam as the majority religion of the Banyuwangi community does not reduce or eliminate the existence of sorcerer in Banyuwangi. Even the Banyuwangi people use sorcery as their identity, such as the city tagline of Banyuwangi as "Banyuwangi, the City of Santet".

Based on above, it appears that the existence of a sorcerer in Banyuwangi is a complicated problem. This is because, the existence of sorcerer is considered as a lie, but on the other hand many people believe in its existence. In general, this study aims to discuss the representational character of the 1998 Banyuwangi sorcerer massacre which is depicted in the novel Perempuan Bersampur Merah (Woman in Red Scarf). There are two focuses of this research, namely how the massacre of the sorcerers is depicted from the perspective of the victim and how the trauma experienced by the victim's family is resulted from the incident. This study provides an overview of the configuration of social and political conflicts from the individual and collective memories of the Banyuwangi community recorded in the novel Perempuan Bersampur Merah (Woman in Red Scarf). Through this study, knowledge is also obtained about how the narrative of the massacre of the sorcerer in Banyuwangi is mediated by literary works and becomes the readers' consumption of what the current generation has not experienced. Ribeiro et al., (2012: 11-12), state that understanding these voices are not only useful for understanding the identity of the present generation in understanding past events, but also becomes a medium for learning and understanding these tragic events from a different perspective. Through this, the memory of the events of the massacre experienced by the victims can be shared with people who did not experience it directly (Hirsch, 2008: 103, 2012: 3; Hoffman, 2004: xv). In other words, post-memory reflection, memory transfer, and remediation of memory representations become very important, especially when the figuration of the past is mediated by literature and becomes the readers' consumption of what future generations have not experienced. Researchers in the fields of art and literature, such as Lachmann (1997) and Bal, Crewe, \& Spitzer (1999) have long emphasized the importance of tracing cultural aspects that are embedded in art or literary products. Literary work is understood as a symbolic form (Cassirer, 1944) of cultural memory (Erll, 2011) because literature is a repertoire of knowledge that is not recorded in historical archives (Kansteiner, 2002; Taylor, 2003).

The memory perspective in literary studies, in particular, focuses on efforts to remember dark events of the past to counter various injustices forgotten by history. Because it emphasizes past temporality and politics, this perspective encourages researchers to question various forms of injustice that have historically occurred in the past and have had traumatic effects on their victims (McGregor, 2013). Hirsch (2008: 107, 2012: 3) states that this memory can be passed on to other people, even to people who have never experienced the event. In this perspective, the memory of the massacre of people suspected of being sorcerers in Banyuwangi can be shared with people who have not experienced it firsthand (Hoffman, 2004). This theory is called post-memory (postmemory). Post-memory is used by Hirsch as a theoretical framework that describes the relationship between generations who have experienced personal, collective, and cultural trauma directly and 
the generations after them (Bezo \& Maggi, 2015; De Menezes, 2012; Hirsch, 2012). The next generation who did not directly experience these events entered into traumatic experiences that occurred in the previous generation through stories, pictures, and various other cultural products (Miklavcic, 2008). This generation is connected to past experiences through cultural products, including literary works (Levey, 2014).

Literary works and memoirs written by the second generation are intended as an attempt to express deep pain and depression for those who witnessed and survived the trauma of history (Hirsch, 2012). Through this, literary works offer a different perspective in understanding events from memories outside the historical discourse that have been understood by society. Through these disclosures, new or different perspectives will be obtained in understanding a historical event, especially the dark history of a nation. In other words, various cultural products become alternative media to fight the grand narrative produced by the ruling regime through historical construction (Alvarado, 2017; Gorrara, 2018). This process can raise a new historical awareness regarding the dark history of a nation or society (DeLugan, 2013). Post-memory is not only important as a theoretical framework that uncovers past memories. This is because post-memory also uncovers social memories involving emotions from past trauma (Frosh, 2019). This is because traumatic events also indirectly contribute to the inherited identity generated through anxiety, fear, sadness, loss, and trauma. The identity of children from generations who have experienced dark past events will also be affected by the traumatic effects experienced by their parents (Jacobs, 2014; van Alphen, 2006). This is similar to children of victims who are suspected of being dukun santet having to experience stigmatization and differences in treatment in the social environment where they live. This happened as a result of the labeling and formation of a new identity as a child of a dukun santet by the surrounding community.

Psycho-historical frameworks, such as post-memory, can be a tool to answer fundamental questions about the relationship between the realities of life and works of art (Bullot \& Reber, 2013). From this point of view, literature becomes an aesthetic medium that connects the reality of human life and the fictional reality of literary works (Sugiarti \& Andalas, 2018). As a representation of life, literary works become aesthetic documents of human life (Farida \& Andalas, 2019).

\section{Method}

This research is a type of qualitative research. The approach used in psycho-historical research. Efforts to understand are directed at the memory and traumatic dimensions of the dark incident of the 1998 Banyuwangi sorcerer massacre, which is described in the novel Perempuan Bersampur Merah. The research data source is a novel entitled Perempuan Bersampur Merah by Intan Andaru published by Gramedia Pustaka Utama in January 2019. The research data used is narrative, dialogue, thoughts, and actions of characters in the story that show the research problem.

The data collection technique was done by using a note-taking technique. In the listening stage, a close-reading is carried out on the unit of events contained in the material object to be recorded on the data card. Through this stage, the data analysis stage is then carried out. At the data analysis stage, the data that has been collected is then reduced according to the representativeness of the research problem. The data is then interpreted by the theory used in the study. To ensure the accuracy of the research results, triangulation was carried out, namely by checking the interpretation of the findings made against the theoretical reference sources used. 


\section{Result and Discussion}

Perempuan Bersampur Merah (Woman in Red Scarf) tells the story of the massacre of people who are considered to be sorcerers and trauma who were presented after the incident. Through the perspective of Sari, the child victim of the massacre, the author highlights the dimensions of the Banyuwangi sorcerer massacre tragedy from the victim's perspective. The following describes the representational character of the 1998 Banyuwangi sorcerer massacre from the perspective of the victims and the physical and psychological trauma experienced by the families of the victims as a result of the events that occurred.

\section{Sari's Father and Muhidin: Victims of the 1998 Banyuwangi Sorcerer Massacre}

As an aesthetic work, the function of literature as a document that records various socio-cultural events in society cannot be eliminated. Literary works offer, reveal, or restore lost experiences and stories from historical archives. As a form that is counter to history, "memory" offers forms of justice outside the strict juridical hegemonic structure and invites individual or group involvement in stories that have not been thought of before (Hirsch, 2012). It is in this function that Perempuan Bersampur Merah (Woman in Red Scarf) works. By filling in the void dimensions of the victim's perspective, Andaru, (2019), provides the perspective of the victim's child, Sari's figure, in seeing the incident against her father who was accused of being a sorcerer. The various killings that occurred are described as starting with the leakage of a government-owned radiogram that asked village officials to record the names of suspected sorcerers for safekeeping (Andaru, 2019: 76-77). This list of names has spread widely to the community, leading to vigilante action at the initiative of the community. Armed with these lists of names, the community carried out massacres against people who were labeled as "sorcerers".

In the novel, there are two victims of the massacre suspected of being sorcerers, namely Sari's father and Muhidin. When viewed from the depiction of the life of the two characters, it is far from the image of a sorcerer in his daily life. Sari's father is a simple man who relies on agricultural produce (Andaru, 2019: 47-48). Now and then he was looking for frogs to sell in the market as a financial addition (Andaru, 2019: 53-57). He is a man who is wise in looking at life. He believes in the harmony of human life and nature. He refused to be a rain handler ${ }^{\mathrm{ii}}$ because the rain was a blessing, not a disaster. If it doesn't rain there will be famine and people will starve. "Why stop a blessing just for the celebration of people last night?" (Andaru, 2019: 48). No different from Sari's father, Muhidin is an ordinary person like any other. He is the father of one child. To support his economic life, his wife opened a small shop, his children farmed and served as a rain charmer. Pak Muhidin "often helps people who have a guard so they are not plagued by rain, often heals sick and possessed people with prayers and a glass of water." (Andaru, 2019: 60-61).

The two figures, Muhidin and Sari's father, do not have odd behavior in everyday life. There was no strange magical ritual activity carried out by the two of them. Even if there are ritual activities carried out, they are preparing flowers for weton ${ }^{\mathrm{iii}}$ salvation or pilgrimages and burning incense at the $\mathrm{T}$-junction of the village road for a baritan ${ }^{\text {iv }}$ event (Andaru, 2019: 61). This image is in stark contrast to the image of sorcerers as a person who can harm others through nudes, tae arrows, and other magical objects. Muhidin and Sari's father, are no more than just a dukun suwuk, namely spiritual figures who are considered capable of treating other people's ailments through prayers (Arini et al., 2016: 330). In his narration, the author describes this incident when Sari's father was asked to treat a child who was fussy crying. He said that if his child got seized because he came out at sunset, while the mother suspected that the child had received black magic from someone. Sari's 
father gave one glass of water, half of it drunk by the mother, the rest smeared on her child's head. After a few seconds, the child calms down (Andaru, 2019: 49-51).

The practice of spiritual healing like that of Sari's father is a practice commonly found by people in Indonesia from ancient times until now. This is because the transmission to become a sorcerer can be done by learning or by lineage (Kasniyah, 2012; Winkelman, 2009). Like Sari's father and Pak Muhidin who gained the skills to become sorcerer after studying from Mbah Wid (Andaru, 2019: 47). Armed with the knowledge obtained from Mbah Wid, both of them were known to the public as a sorcerer who was able to help various calamities experienced by the community. However, it was because of his ability to help that person both of them had to die in an unlucky way. Narratively, the murder victim who was accused of being a sorcerer was the result of local actors holding a grudge against these dukun suwuk. They think that the various misfortunes that have happened to them are caused by them, none other Ethan Muhidin and Sari's father.

The various accusations addressed to these victims are the superficiality of people's thinking. Mr. Ngadino's wife suffered from stinky buttocks and back injuries. Her feet are rotting. Even when washed, the wound is black and some maggots are falling (Andaru, 2019: 33). Saiman's wife died in the womb of his wife while defecating (Andaru, 2019:35). She often imagines that her child visits her in her dreams. Mr. Tuki Bebek's wife is paralyzed, has a lump in her neck that is getting bigger and thinner (Andaru, 2019:36-37). Mr. Tuki and the villagers believe that his wife is affected by a post-borne disease (Andaru, 2019: 37). Mr. Sotar, because he has problems fighting over inherited land with his brother, often gets grumpy until he has an affair with Mak Rebyak and is caught by his wife. He accused Sari's father of helping his brother to send sorcerer to him (Andaru, 2019: 134). Rama's father considered that his son's death was caused by sorcerer sent by Sari's father (Andaru, 2019: 198).

These various events show the knowledge system that grew and developed in the Banyuwangi community at that time. Borrowing Comte's point of view (Ackerman, 2002: 9), at this time people's knowledge is still at a magical stage when humans connect phenomena around them with various supernatural powers. This is reinforced by the still strong influence of tradition in the life of the Banyuwangi community at that time. Various things that happen in their lives are still considered closely related to the supernatural powers that are around them. In the novel, this can be seen from the still deeply rooted tradition of cleaning the village complete with offerings and processions of Dewi Sri and keboan ${ }^{\text {vi }}$ (Andaru, 2019: 11-14) as an expression of gratitude for the abundant harvest. Sari is often sickly so she has to change her name because her name is considered unsuitable (Andaru, 2019: 94). This includes the behavior of people who still believe in sorcerers as people who can help heal illnesses or ward off rain. These various events show the knowledge system that grew and developed in the Banyuwangi community at that time. Borrowing Comte's point of view (Ackerman, 2002: 9), at this time people's knowledge is still at a magical stage, when humans connect phenomena around them with various supernatural powers. This is reinforced by the still strong influence of tradition in the life of the Banyuwangi community at that time. Various things that happen in their lives are still considered closely related to the supernatural powers that are around them. In the novel, this can be seen from the still deeply rooted tradition of cleaning the village complete with offerings and processions of Dewi Sri and keboan (Andaru, 2019: 11-14) as an expression of gratitude for the abundant harvest. Sari is often sickly so she has to change her name because her name is considered unsuitable (Andaru, 2019: 94). This includes the behavior of people who still believe in sorcerers as people who can help heal illnesses or ward off rain.

When viewed from the current perspective, the various diseases experienced by people in Sari village can be explained medically and not due to sorcerer. Indeed, it should be understood 
that in a traditional society like this, the perception of the emergence of disease in society is often perceived in two forms, namely naturalistic (environmental) or personalistic (intervention of supernatural beings) (Foster, 1986). However, the various illnesses suffered by the perpetrators' families were the "excuses" they used to resolve their hurt feelings toward Pak Muhidin and Sari's father, who were accused of being sorcerers. Muhidin and Sari's father are murder victims who should receive protection from justice. When viewed carefully, the motives described in this novel are in line with the results of field research conducted by Siegel (2006). He showed that based on interviews with the perpetrators of the massacre and the surrounding community there was no authentic evidence to support the allegation that the person they killed was a sorcerer. Everything is only based on prejudice (Siegel, 2006: 118). In looking at this issue, the author agrees with Herriman (2006:365), that "the murder of a suspected dukun santet must be understood as a local phenomenon, in which neighbors, family, and people around suspect one of them to be a dukun santet". The public's ignorance occurs because mysticism is still deeply rooted. Various things that are not logically explained to become the basis for justifying the act of murder.

The depiction of the 1998 Banyuwangi tragedy in this work of fiction is a form of what Asmann (Patiño-Lakatos, 2019: 56) calls a "counter-memory" which functions to interrogate the collective memory that is built up in the general public in seeing the events of the 1998 Banyuwangi tragedy. The novel is a creative work that provides resistance in a counter-narrative form. This method is a form of a narrative strategy used by the author in exposing the different images in the collective memory of the community regarding the 1998 Banyuwangi tragedy and marginal voices in the victim's perspective. The 1998 incident was re-contextualized through this novel not only in realist aesthetics but also in recurring metaphors. This figure of speech, to borrow Baetens' (2002: 356) term, is referred to as etymon, which is a narrative motif that always recurs and offers multiple readings. In a woman mixed with red, "unexplained sickness and death" is etymon because through understanding this dimension, the reader can interpret a work as a whole.

\section{Massacre Trauma: Traumatized Child of Victims}

Massacre Trauma is a condition in which the subject feels intense fear, feels helpless, loses control, and is threatened (Herman, 2015: 33). In his study of victims of the Holocaust tragedy, Hirsch (2008, 2012) shows that post-tragedy trauma is not only experienced by eyewitnesses of the event but can also be passed on to subsequent generations. This shows that trauma, especially in events involving mass tragedies, cannot be viewed as individual trauma that will just disappear as events in society are forgotten. Sari in Woman in Red Sarf is a description of the children who were victims of the dukun santet massacre. Sari's character in the novel becomes an "intermediate" character who acts as an agent who voices protests against the construction of events in society. It is not only a picture of child victims of the massacre but also a symbol of the "despair" of child victims after the incident who must inherit individual trauma and be forgotten in society.

Described in the first-person perspective, Sari witnessed how helpless her father was in facing groups of people who wanted his father's life. The incident is described in the narrative, "The man who was howling for help was not heeded at all. Even my close neighbors who woke up to the crowd that night couldn't do anything.... " (Andaru, 2019: 68). This illustration shows the situation that occurred when Sari's father was about to be killed by villagers who accused him of being a sorcerer. The power of the people who wanted to kill Mr Sari could not be abated or resisted, so the surrounding community preferred to remain silent. What was excessively traumatized in the Banyuwangi 1998 incident was the way victims who were suspected of being sorcerers were killed. 
In the novel, through a first-person perspective, it is clearly depicted. "There are cuts on his neck that look terrible. The blood clotted, clinging to his pale body." (Andaru, 2019: 68). This description shows the condition of Sari's father after the murder. By providing an overview and emphasis on the way victims were killed, this novel explores the psychological trauma of victims in a way that is rarely exposed by mainstream memoirs, thereby giving readers a new dimension to the depth of trauma experienced by victims' families.

As a 5-year-old child, Sari has to witness how her father was killed and this trauma will become a memory part of her life. Trauma as experienced by Sari is a form of symbolic death (Goldberg, 2017: 76) or in Lacan's term (2013) is referred to as a second death. Symbolic death is not a natural death based on fate, but what happens to Sari when she sees her father's death is a form of destruction of the symbolic universe, namely the cultural system by which we make the world meaningful (Žižek, 1989: 134). As a child who saw firsthand how his father was killed by a group of people who accused him of being a sorcerer, Sari's trauma certainly could not go away. However, what will happen to the children of these victims in the future also raises a question mark. Narrative, the novel clearly describes how the murder of his father finally changed his attitude in seeing the people around him. The fear of being the child accused of sorcerer had always overshadowed him from childhood to adulthood.

What the author describes in the novel is in harmony with what happens in real life. The child victims of the massacre, like Sari, did not get attention, especially the psychological traumas that should not have been borne by them. This is because at least it is based on two things, namely the absence of evidence that can prove that the victims are sorcerers and the trauma of the victim's family must be treated. This is because the trauma that occurs in the victim's family, such as Sari and her mother, is a form of deep trauma. In the narrative, this description can be seen in the following quote.

"Every time I look outside the house, I really can feel what happened that night: My memory of the mob who surrounded the house. Thrilling noise. The noise that made us tremble. Also, those who hurt my father: people I didn't know and some of the neighbors who followed them from behind. In the dark, I was able to see and record anyone who looked with pity and helped our family, as well as anyone who looked hatefully at you. " (Andaru, 2019: 70).

These memories are a form of tragic memory and often form the basis for the formation of future subjects. That is, childhood experiences shape individual characters in their life journey. As a result of dark events in her past, it will help shape Sari's identity in the future. The trauma experienced by the families of massacre victims such as Sari is not only in the form of individual trauma, but also causes cultural trauma. The stigmatization that was given to Sari by others with the label "child of the sorcerer" is a manifestation of this trauma. This stigmatization has an impact on the familial and individual identity of the victim's family. "Don't marry him, he's the son of a sorcerer." (Andaru, 2019: 9). Or Ayu and Rama's friendship must be prevented by Rama's father because Ayu is the child of a magician (Andaru, 2019: 26-27).

What happened to Sari is a picture of cultural trauma, which is trauma to a collective member that leaves an irreversible trail and changes their identity in the future that cannot be changed (Alexander, 2016: 4). This cultural trauma occurs mainly in events where the point of light cannot be found so that the stigmatization that is generated through repeated discourse becomes as if it is the right thing. This cultural trauma for social, cultural, and national groups does not only illustrate the suffering of marginalized groups, such as Sari, but also presents a moral responsibility to be resolved. 


\section{Conclusion}

Through the analysis that has been carried out, it appears that this work is a creative work that provides resistance in a counter-narrative form. This work provides a cultural overview of the Banyuwangi 1998 incident. There is no authentic evidence to support the allegation that the person they killed was actually a sorcerer. Everything is based on prejudice. As a result of this incident, not only the murder victim, the suspected dukun santet, became the victim, but also his family. Individually, psychic traumas of the shadow of death always haunt Sari's life until adulthood. However, cultural trauma becomes a trauma that cannot be erased because stigmatization as a descendant of a sorcerer will always stick with him. This cultural trauma for social, cultural, and national groups does not only illustrate the suffering of marginalized groups, such as Sari, but also presents a moral responsibility to be resolved. This work of fiction revives the social and cultural memorial structure of the 1998 Banyuwangi sorcerer massacre in the form of aesthetic mediation to activate historical memory, whether individuals or groups experiencing it directly or not (postmemory generation). This memory becomes a medium for learning and understanding tragic events from a different perspective. This novel is a cultural memory of the community in remembering the tragedy of the 1998 Banyuwangi sorcerer massacre.

\section{Funding Disclosure/Acknowledgement}

The author would like to thank the Rector of the University of Muhammadiyah Malang and Directorate of Research and Community Service University of Muhammadiyah Malang who have financed this research.

\section{Notes}

${ }^{\text {i }}$ Sorcerers (Dukun Santet) is a person who practices black magic to harm others. Victims usually feel stomach pain, vomit blood, have a fever, and even find objects such as nails or needles in their stomach. This black magic has been known for decades in Indonesia, especially in Java. Banyuwangi, one of the districts in Indonesia, is known as an area that has many shamans.

ii In Java, when there is a big event, usually the rain handler is hired to ward off the rain. This is one of the beliefs that grows in society. Sorcerers not only master black magic, but also help the community.

iii Weton is the day of birth according to the Javanese calendar which is commonly used as a good predictor to determine a partner's compatibility, determine a person's character, fortune, match and success.

iv The Baritan tradition is a traditional ceremony related to community beliefs and natural events. This tradition grows and develops in the lives of people who make a living as farmers and fishermen. Baritan aims as an expression of gratitude to God who has provided abundant crops.

${ }^{\mathrm{v}}$ Dukun suwuk is someone who is able to treat other people's ailments through traditional medicine by using mantras and chanting prayers mediated by water or potions from plants.

vi One of the customs of the Indonesian people, especially Java and Sundanese, which is carried out to welcome the arrival of the big harvest as a form of gratitude to God Almighty

\section{References}

Ackerman, R. (2002). The Myth and Ritual School: J. G. Frazer and Cambridge Ritualist. Routledge. 
Alexander, J. C. (2016). Culture trauma, morality and solidarity: The social construction of 'Holocaust' and other mass murders. Thesis Eleven, 132(1), 3-16. https://doi.org/10.1177/0725513615625239

Alvarado, K. O. (2017). Cultural memory and making by US Central Americans. Latino Studies, 15(4), 476497. https://doi.org/10.1057/s41276-017-0093-8

Andaru, I. (2019). Perempuan Bersampur Merah. Gramedia.

Arini, R. T., Alimi, M. Y., \& Gunawan, G. (2016). The Role of Dukun Suwuk and Dukun Prewangan in Curing Diseases in Kediri Community. Komunitas: International Journal of Indonesian Society and Culture, 8(2), 328-338. https://doi.org/10.15294/komunitas.v8i2.4461

Asrumi, A. (2017). Tradisi Basanan dan Mantra Santet Osing sebagai Wujud Kearifan Lokal dalam Meredam Konflik. In Wiyatmi, D. Budiyanto, \& Kusmarwanti (Eds.), Sastra: Merajut Keberagaman, Mengukuhkan Kebangsaan (pp. 384-434). Himpunan Sarjana Kesusastraan Indonesia (HISKI) Komisariat Universitas Negeri Yogyakarta.

Baetens, J. (2002). History against the grain? Rethinking History, 6(3), 345-356. https://doi.org/10.108o/13642520210164788

Bal, M., Crewe, J., \& Spitzer, L. (1999). Acts of Memory: Cultural Recall in the Present. University Press of New England.

Bezo, B., \& Maggi, S. (2015). Social Science \& Medicine Living in " survival mode : " Intergenerational transmission of trauma from the Holodomor genocide of 1932 e 1933 in Ukraine. Social Science \& Medicine, 134, 87-94. https://doi.org/10.1016/j.socscimed.2015.04.009

Bullot, N. J., \& Reber, R. (2013). The artful mind meets art history : Toward a psycho-historical framework for the science of art appreciation. BEHAVIORAL AND BRAIN SCIENCES, 36, 123-180. https://doi.org/10.1017/So140525X12000489

Cassirer, E. (1944). An Essay on Man: An Introduction to a Philosophy of Human Culture. Yale University Press.

Colombijn, F., \& Lindblad, J. T. (2002). Introduction. In F. Colombijn \& J. T. Lindblad (Eds.), Roots of violence in Indonesia: Contemporary violence in historical 2perspective (pp. 1-31). KITLV Press.

Cribb, R. (2001). How many deaths? Problems in the statistics of massacre in Indonesia (1965-1966) and East Timor (1975-1980). In I. Wessel \& G. Wimhofer (Eds.), Violence in Indonesia (pp. 82-98). Abera.

Cribb, R. (2002). From total people's defence to massacre: Explaining Indonesian military violence in East Timor. In F. Colombijn \& J. T. Lindblad (Eds.), Roots of violence in Indonesia: Contemporary violence in historical perspective (pp. 227-241). KITLV Press.

De Menezes, A. R. (2012). Family memories, postmemory, and the rupture of tradition in Josefina Aldecoa's Civil War trilogy. Hispanic Research Journal, 13(3), 250-263. https://doi.org/10.1179/1468273712Z.ooooooooo14

DeLugan, R. M. (2013). Commemorating from the Margins of the Nation: El Salvador 1932, Indigeneity, and Transnational Belonging. Anthropological Quarterly, 86(4), 965-994. https://doi.org/10.1353/anq.2013.0046

Erll, A. (2011). Media and Cultural Memory. Palgrave Macmillan.

Farida, N., \& Andalas, E. F. (2019). Representasi Kesenjangan Sosial-Ekonomi Masyarakat Pesisir dengan Perkotaan dalam Novel Gadis Pantai karya Pramodya Ananta Toer. KEMBARA: Jurnal Keilmuan Bahasa, Sastra, Dan Pengajarannya, 5(1), 74-9o. https://doi.org/10.22219/kembara.v5i1.7447

Foster, G. M. (1986). Antropologi Kesehatan. Penerbit Universitas Indonesia.

Frosh, S. (2019). Postmemory. American Journal of Psychoanalysis, 79(2), 156-173. https://doi.org/10.1057/s11231-019-09185-3 
Goldberg, A. (2017). Trauma in First Person: Dary Writing During the Holocaust. Indiana University Press.

Gorrara, C. (2018). Black October comics, memory, and cultural representations of 17 October 1961. French Politics, Culture and Society, 36(1), 128-147. https://doi.org/10.3167/fpcs.2018.360106

Hariadi, L. K. (2004). Kiamat Para Dukun. Era Intermedia.

Herman, J. (2015). Trauma and Recovery: The Aftermath of Violence From Domestic Abuse to Political Terror. Basic Books.

Herniti, E. (2012). Kepercayaan Masyarakat Jawa Terhadap Santet, Wangsit, dan Roh Menurut EdwardPritchard. Thaqafiyyat, 13(2), 384-400.

Herriman, N. (2006). Fear and uncertainty: Local perceptions of the sorcerer and the state in an Indonesian witch-hunt. Asian Journal of Social Science, 34(3), 36o-387. https://doi.org/10.1163/156853106778048669

Herriman, N. (2007a). A Din of Whispers : Community, State Control, and Violence in Indonesia. The University of Western Australia.

Herriman, N. (2007b). "Sorcerer" Killings in Banyuwangi: a Re-Examination of State Responsibility for Violence. Asian Studies Review, 31(31), 61-78. https://doi.org/10.1080/10357820701196692

Herriman, N. (2009). A Din of Whispers: The in Group Manifestation of Sorcery in Rural Banyuwangi. Anthropological Forum, 19(2), 119-141. https://doi.org/10.1080/oo664670902980371

Herriman, N. (2010). The Great Rumor Mill: Gossip, Mass Media, and the Ninja Fear. The Journal of Asian Studies, 69(3), 723-748. https://doi.org/10.1017/Soo21911810001488

Herriman, N. (2012). Sorcery, Theft and Affinity: The Estrangement of Intimacy in Eastern Java. The Asia Pacific Journal of Anthropology, 13(5), 454-468.

Herriman, N. (2015a). "Hard-copy rumours": Print media and rumour in Indonesia. South East Asia Research, 23(1), 45-6o. https://doi.org/10.5367/sear.2015.0247

Herriman, N. (2015b). The Morbid Nexus: Reciprocity and Sorcery in Rural East Java. Australian Journal of Anthropology, 26(2), 255-275. https://doi.org/10.1111/taja.12110

Hirsch, M. (2008). The Generation of Postmemory. Poetic Today, 29(1), 103-128. https://doi.org/10.1215/03335372-2007-019

Hirsch, M. (2012). The Generation of Postmemory: Writing and Visual Culture After the Holocaust. Columbia University Press.

Hoffman, E. (2004). After Such Knowledge: Memory, History, and the Legacy of the Holocaust. Public Affairs.

Jacobs, J. (2014). Sites of Terror and the Role of Memory in Shaping Identity Among First Generation Descendants of the Holocaust. Qual Sociol, 37, 27-42. https://doi.org/10.1007/s11133-013-9270-8

Juang, R. P., Erviantono, T., \& Azhar, M. A. (1998). HAM dan Politik Kriminal Pasca Orde Baru (Konstruksi Pelanggaran HAM pada Kasus Pembantaian Dukun Santet di Kabupaten Banyuwangi Tahun 1998). Politika, 1(1), 1-8.

Kansteiner, W. (2002). Finding Meaning in Memory: A Methodological Critique of Collective Memory Studies. History and Theory, 41(2), 179-197.

Kasniyah, N. (2012). Fenomena Budaya Dalam Penyembuhan Penyakit Secara Tradisional: Pijat Refleksi dan Transfer Penyakit dengan Media Binatang. Media Masyarakat Kebudayaan Dan Politik, 22(4), 333-342.

Khusairi, L. (2015). Ontran-Ontran Demokrasi: Kekerasan dengan Isu Dukun Santet di Banyuwangi 19981999. Universitas Gadjah Mada.

Lacan, J. (2013). The ethics of psychoanalysis 1959-1960: The seminar of Jacques Lacan. Routledge. 
Lachmann, R. (1997). Memory and Literature: Intertextuality in Russian Modernism, Theory and History of Literature. University of Minnesota Press.

Levey, C. (2014). Of HIJOS and Niños: Revisiting Postmemory in Post-Dictatorship Uruguay. History \& Memory, 26(2), 5-39.

Mahony, I. (2002). The Role of Dukun in Contemporary East Java: A Case Study of Banyuwangi Dukun (Issue December). http://www.acicis.edu.au/wp-content/uploads/2015/o3/MAHONY-Inez.pdf

McGregor, K. E. (2013). Memory Studies and Human Rights in Indonesia. Asian Studies Review, 37(3), 350361. https://doi.org/10.1080/10357823.2013.792782

Miklavcic, A. (2008). Slogans and graffiti: Postmemory among youth in the Italo-Slovenian borderland. American Ethnologist, 35(3), 440-453. https://doi.org/10.1111/j.1548-1425.2008.00045.X

Parker, L. (2003). From Subjects to Citizens: Balinese Villagers in the Indonesian Nation-State. Nordic Institute of Asian Studies Press.

Patiño-Lakatos, G. (2019). Trace and Memory of Trauma: From Bodily Memory to Symbolic Memory. L'Évolution Psychiatrique, 84(3), 45-58. https://doi.org/Patiño-Lakatos, G. (2019). Trace and Memory of Trauma: From Bodily Memory to Symbolic Memory. L'Évolution Psychiatrique. doi:10.1016/j.evopsy.2019.05.002

Retsikas, K. (2006). The Semiotics of Violence: Ninja, Sorcerers, and State Terror in Post-Soeharto Indonesia. Bijdragen Tot de Taal-, Land- En Volkenkunde, 162(1), 56-94. http://www.jstor.org/stable/27868286

Retsikas, K. (2010). The sorcery of gender: Sex, death and difference in East Java, Indonesia. South East Asia Research, 18(3), 471-502. https://doi.org/10.5367/sear.2010.0001

Ribeiro, M. C., Vecchi, R., \& Ribeiro, A. S. (2012). The Children of the Colonial War: Post-Memory and Representations. In I. C. Gil \& A. Martins (Eds.), Plots of War: Modern Narratives of Conflict (pp. 11-23). Walter de Gruyter GmbH.

Siegel, J. T. (2001). Suharto, Witches. Indonesia, 71(April), 27-78. https://doi.org/10.2307/3351456

Siegel, J. T. (2002). Some Views of East Javanese Sorcery. Archipel, 64(1), 163-18o. https://doi.org/10.3406/arch.2002.3731

Siegel, J. T. (2006). Naming The Witch (M. Bal \& H. de Vries (eds.)). Stanford University Press.

Singodimayan, H. (2003). Kerudung Santet Gandrung. Desantara.

Subekti, A., \& Kusairi, L. (2018). From Sunrise of Java to Santet of Java: Recent Urban Symbolism Of Banyuwangi, Indonesia. In Warsono, Hartono, S. Bachri, \& A. Purnomo (Eds.), ist International Conference on Social Knowledge Sciences and Education (ICSKSE 2018) (Vol. 320, pp. 144-147). Atlantis Press. https://doi.org/10.2991/icskse-18.2019.28

Sugiarti, S., \& Andalas, E. F. (2018). Pespektif Etik dalam Penelitian Sastra. UMM Press.

Taylor, D. (2003). The Archive and the Repertoire: Performing Cultural Memory in the Americas. Duke University Press.

van Alphen, E. (2006). Second-generation testimony, transmission of trauma, and postmemory. Poetics Today, 27(2), 474-488. https://doi.org/10.1215/03335372-2005-015

Vickers, A. (2010). Where Are the Bodies: The Haunting of Indonesia. The Public Historian, 32(1), 45-58. https://doi.org/10.1525/tph.2010.32.1.45

Wessing, R. (1996). Rumours of sorcery at an Indonesian university. Journal of Southeast Asian Studies, 27(2), 261-279. https://doi.org/10.1017/Soo22463400021056 
13 Remembering the 1998 Indonesian Sorcerers Massacre: Memory of Tragedy and Trauma in Intan Andaru's Perempuan Bersampur Merah (Woman in Red Scarf)

Winandi, W. (2001). Perlindungan Hukum Terhadap Korban Pelanggaran Hak Asasi Manusia dalam Kerusuhan Massal Pada Kasus Pembantaian Dukun Santet di Banyuwangi. Universitas Diponegoro.

Winkelman, M. (2009). Sorcererism and the Origins of Spirituality and Ritual Healing. Journal for the Study of Religion, Nature \& Culture, 3(4), 458-489. https://doi.org/10.1558/jsrnc.v3i4.458

Žižek, S. (1989). The Sublime Object of Ideology. Verso. 